\title{
Developing a model of employment creation in border region: Gaharu cultivation and honey bee farming in Bengkayang, West Kalimantan, Indonesia
}

\author{
NURUL BARIYAH \\ Department of Economics and Development Study, Faculty of Economics \& Business, Universitas Tanjungpura. Jl. Prof. Dr. H. Hadari Nawawi, \\ Pontianak 78124, West Kalimantan, Indonesia. Tel.: +62-561-785342, 583865, Fax.: +62-561-765342, `email: nurul.bariyah@ekonomi.untan.ac.id
}

Manuscript received: 3 September 2020. Revision accepted: 17 October 2020

\begin{abstract}
Bariyah N. 2020. Developing a model of employment creation in border region: Gaharu cultivation and honey bee farming in Bengkayang, West Kalimantan, Indonesia. Biodiversitas 21: 5237-5247. The border regions possess political, cultural, and socioeconomic complexity. One of major problems in the border regions is the lack of employment opportunity following ups and downs in the economy, suggesting a need for a more sustainable employment opportunity by harnessing local conditions and practices. The main objective of the research was to construct an economic development model in the border region by integrating available natural resources, local initiatives, and external support to provide employment opportunities. We conducted the research in Jagoi Village, Bengkayang District, West Kalimantan, Indonesia which has border with Sarawak, Malaysia. We collected primary data through indepth interviews, structured interviews, observation, and focus group discussion combined with secondary data. This information was then used to construct the model. Our research found that the population of Jagoi Village consisted of farmers (50\%), menial laborers $(30 \%)$, traders (17\%), civil servants (2\%), and ojek taxi drivers (1\%). In the past, they also received additional income from collecting wild bee honey and gaharu (agarwood) resin. However, large tracks of forest area were cut by commercial loggers or converted into oil palm plantations. Fortunately, Jagoi Village has adat forest which preserved the forest from the expansion of oil palm plantation and is a source of non-wood products to use by the community could use. The research revealed that collecting wild bee honey and gaharu was no longer viable. Started from these conditions, we proposed a model of employment creation by cultivating gaharu and farming honey bee. As such, there is paradigm change from 'collecting' or 'gathering' into 'cultivation' and farming. To be successful, the model integrates six elements, consisting of awareness building, local initiatives, success stories as an example, external support or empowerment, field school, and independent execution. Using this approach the target community will be able to create new employment opportunities which eventually increases their income and prosperity.
\end{abstract}

Keywords: Adat forest, cultivation, employment, gaharu, wild bee honey

\section{INTRODUCTION}

The border region of two or more countries always triggers complexity, not only in term of politics, but also in cultural and socio-economic aspect. That is the case of Bengkayang, a district in West Kalimantan, Indonesia which has border lines with Sarawak, Malaysia. In the cultural aspects, this region is a unique and strategic transitional area between the two countries with relatively similar cultural traditions although with somewhat different colonial history, i.e. Indonesia with the Dutch (Netherland) and Malaysia with the British Empire.

From the socio-economic perspective, Bengkayang region is quite far from Pontianak, the provincial capital and center of growth in the province, and much closer to Kuching, the state capital of Sarawak. As a consequence, the area suffers from lack of infrastructure developments, and prone to illegal trade, human trafficking, and other trans-border criminal acts. Also, the border population suffers from low-level of formal education, although some people have additional experience working across the border. However, because of their limited education, they have to accept low-level employment and low wages from their employers in the neighboring country. Some of them work as house helpers, café attendants, shop keepers, and become menial laborers at oil palm plantations and various industries.

Due to its close proximity to Sarawak, the population of Bengkayang accrues mutual benefits from the linkages established between the two regions as well as becomes vulnerable when drastic downturn in global economy or other socio-political problems. For example, during the 1980s and 1990s, Bengkayang enjoyed great fortune derived from logging. However, due to unsustainable exploitation of forest resources, particularly wood, the timber business plummeted, leaving the rural workforce without jobs and had to fall back on their age-old cushion of subsistence farming, rubber tapping, planting of oil palm, ojek (motorcycle taxi) drivers, etc., or become migrant workers or commute across the border to get a job.

Realizing the difficulty to increase the outputs of traditional farming, the risk of transporting goods and people across the border, and the low reward working as menial labors, alternative livelihoods of natural resource management in Bengkayang region are needed. These alternative livelihoods should be environmentally 
sustainable by using relatively low and affordable inputs of capital and technology. The Food and Agriculture Organization of the United Nations (FAO, 2013) stated that it is necessary to provide decent employment in forestry by using sustainable approach, since it is a key to improve food security and nutrition for those who rely on forest for their livelihood. Azra (2015) discussed the factors responsible for the dependence of local communities on forest resources that might threaten forest sustainability.

Two potential livelihoods to promote in Bengkayang that incorporate economic as well as environmental consideration are wild bee honey farming and gaharu (an Indonesian term for agarwood) cultivation. Forested landscapes in Kalimantan, including in Bengkayang, have high richness and abundance of native bees (Watson et al. 2011). In addition, Soehartono and Newton (2002) stated that the harvesting of wild population of gaharu has been in a decline and is about to progress to a cultivation phase according to the Homma model (Homma 1996). The potential of gaharu to be cultivated is high due to its wide habitat distribution, especially on upland marginal soils. It also has a high potential profit margin, due to its unusual economic and biological properties, it is nonperishable, and its major markets are international in nature (Paoli et al. 2001).

With such incentives in place, it is logical to assume that some measures of conservation and management are in place and enforced by the locals, if only to ensure a steady income (Wollenberg 2001). It is thus imperative that decision-makers are to develop new policies that enable traditional communities to enhance their standard of living whilst also minimizing the impacts of development on the environment (Nugroho et al. 2018). Kanwal et al. (2017) revealed that the implementation of forest development program has succeeded in generating income and employment for the community in the forest area. For the sake of sustainable forest exploitation, extraction of nonwood forest products, such as honey bee and gaharu, presents a low environmental impact (Filho and Fachinello 2015). As stated by $\mathrm{Ng}$ 'andwe et al. (2015), the contribution of forestry, wood, and non-wood products processing activities can ensure food security and alleviate poverty.

In line with recent trend toward global sustainable forest management (MacDicken et al. 2015; Clark and Kozar 2011), the main objective in this research was to construct an economic development model for the border region, in this context is Bengkayang, by integrating available natural resources, local initiatives, and external support. Bengkayang District is an excellent case study as the region is rich in natural resources such as natural forest, inland waters, endemic flora, and fauna. Many of the flora and fauna species are yet to be identified, while some are already listed as endangered species, including agarwood (Aquilaria malaccensis) and orangutan (Pongo pygmaeus). Most of the population Bengkayang still adhere to their traditional lifestyle and use natural resources using traditional methods. To improve their ability to overcome the effects of economic downturn that often hit the area, the community in the border needs external support. Using their local wisdom and knowledge in combination with external help, the community will develop new skills, finance, and management capability.

Our research will introduce new ways of dealing with two commodities (i.e. gaharu and wild bee honey) that local communities in Bengkayang could no longer handle with their own traditional knowledge. However, in view of their familiarity and wisdom, gaharu trees and wild honey bees should not be left aside and perish, because there are ways how that knowledge and wisdom can be preserved by adding new elements derived from external sources, i.e. methods and techniques of gaharu and honey bees cultivation.

This study, in essence, is rounding all available resource potentials and putting them together in a practical and workable scenario where every party could contribute to successful economic development and improvement of social welfare for local communities. We expected that our approach would reap support from all parties concerned with the development of local communities in the border region in particular, and West Kalimantan in general. Based on our frequent engagements with the local communities at the border region we recognized that they prefer to use their local knowledge and wisdom as essential part of harnessing abundant natural resources they have. The expert from universities is also eager to venture into the grassroots where they can make the most of what expertise and skill they have accumulated through teaching and research at the universities. The local government would certainly support companionship effort which encourages sustainable development initiative and green economy principle. By doing this we could contribute to promote sustainable development and green economy principle.

\section{MATERIALS AND METHODS}

\section{Study area}

This study was conducted in Bengkayang District (Figure 1), which is one of twelve districts and two municipalities in West Kalimantan Province, and one of five districts (i.e. Sambas, Bengkayang, Sintang, Sanggau, and Kapuas Hulu) in the province that share borders with Sarawak, Malaysia. Bengkayang District has 17 subdistricts and Jagoi Babang is one of them.

The study site was Jagoi Village, one of six villages (i.e. Jagoi, Sekida, Sinar Baru, Semunying Jaya, Kumba, and Gersik) in Jagoi Babang Subdistrict and one of three villages (Seluas, Jagoi Babang, and Siding) that share border with Kampong Serikin, Sarawak. Jagoi Village had 549 households, consisted of 1,300 males and 1,195 females, totaling 2,495 individuals. Most of the population were of Iban and Bidayuh Dayak ethnic group and so was the population of Serikin. The similarity in ethnicity facilitates smooth and easy communication and mobility between the two communities that are formally separated by the borderline between Indonesia and Malaysia. The research site is surrounded by forest area that has been declared as adat forest (adat is custom or accepted practice 
of local community) and therefore is saved from expansion of oil palm plantations that converted large forest area into oil palm monoculture stands. The occurrence of the adat forest in this village is, among others, the rationale of the selection of village to be developed into project that combines the principles of green economy and community welfare (Figure 2).

\section{Research method}

This study employed a qualitative method. In contrast to quantitative method that aims at providing proof or verification to a proposition, qualitative method is more concerned with providing better knowledge and understanding about certain phenomena at hand, and in our case, the problem of idle rural workforce and available choices to solve it. Most of the data were qualitative, although some nominal quantitative data were also collected. The nominal data were utilized to clarify certain aspects of the phenomena which further explained in narrative fashion. The qualitative data were textual information collected through open-ended questions during interview or retrieved from external documents. The qualitative data were used in textual explanation, instead of statistical computation.
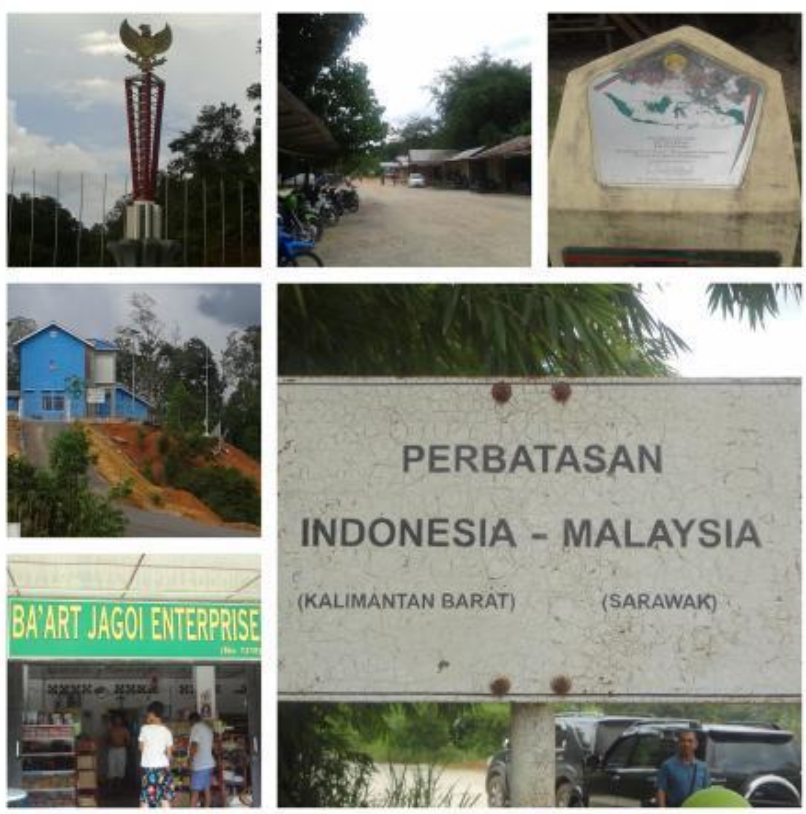

Figure 2. Study site
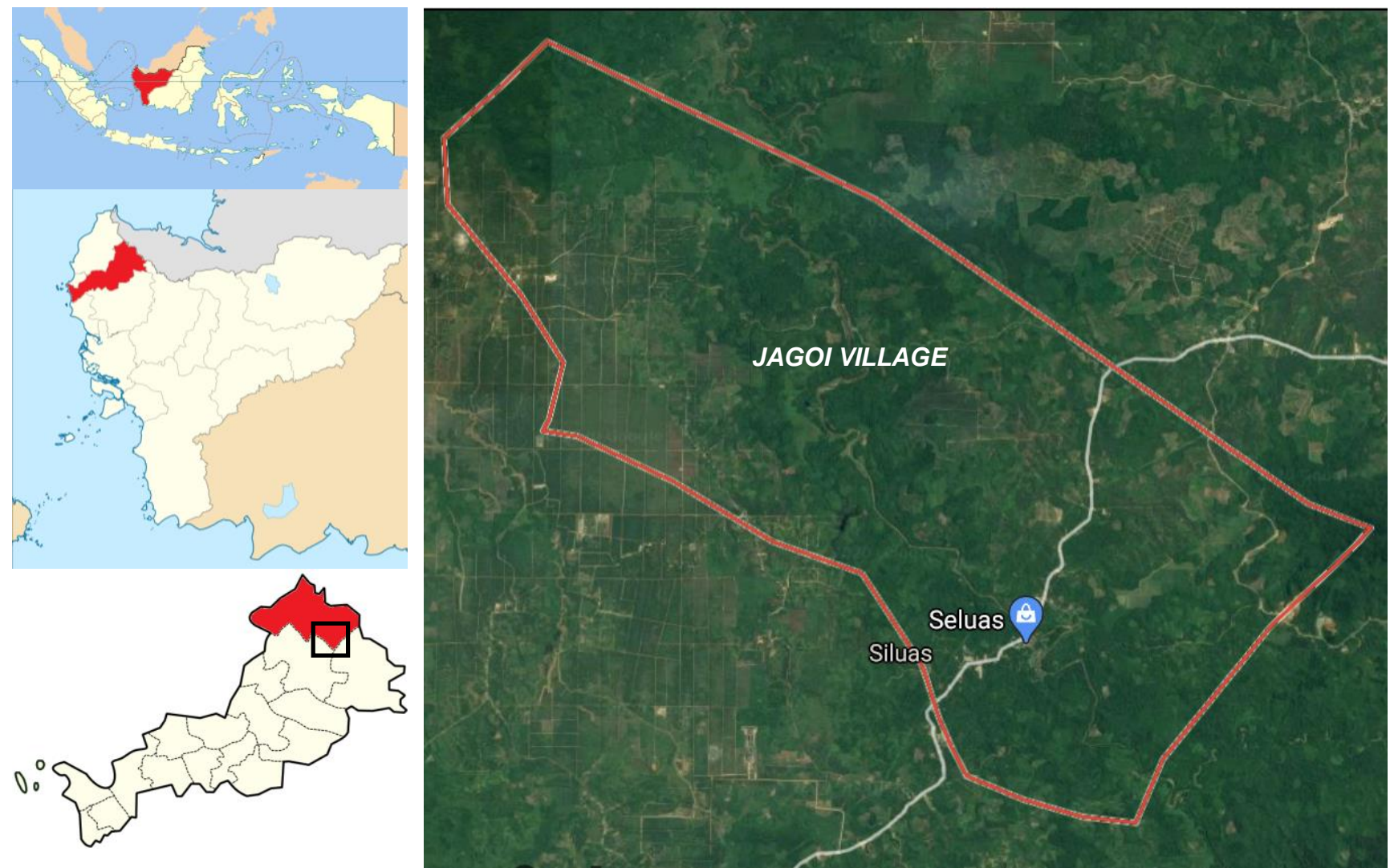

Figure 1. Map of study site in Jagoi Village, Jagoi Babang Subdistrict, Bengkayang District, West Kalimantan Province, Indonesia. Source: Googlemap \& Wikipedia 


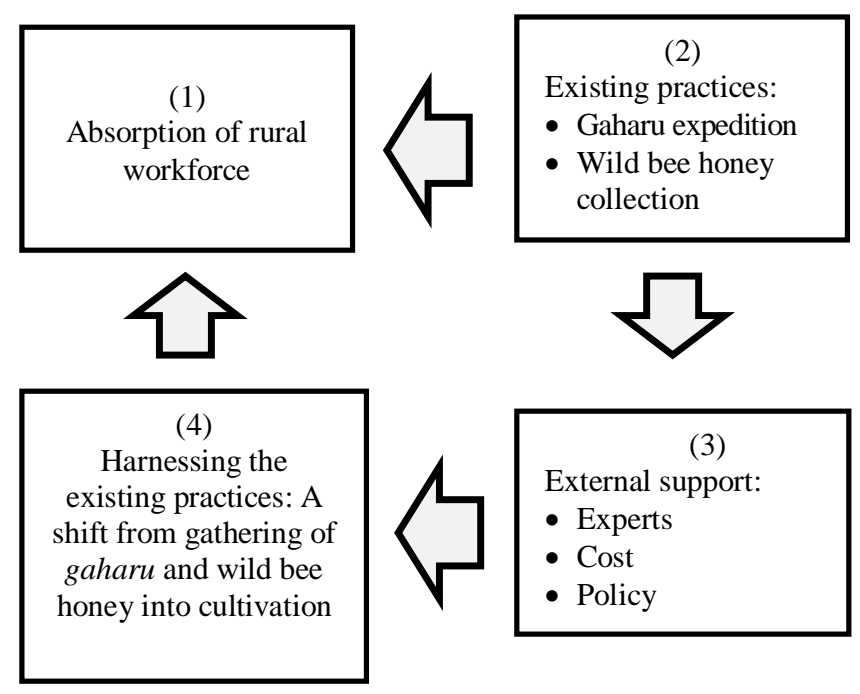

Figure 3. Conceptual framework proposed in this study

\section{Conceptual framework}

Earlier studies have looked into the relationship between aspects of natural resources and job creation and income generation. Kimengsi and Ngala (2018) found relationship between employment creation and forest management, although there was not enough evidence of income generation. Non-timber forest products, among others, will contribute to the economic diversification in the near future (Kikuchi 2011). Theoretically speaking, the effort to increase absorption of rural workforce can be achieved by harnessing local resources sustainably. If such endeavor can be done, the idle workforce can be utilized optimally and local income and community welfare will increase gradually. Since the local workforce in Bengkayang already tried some of them but didn't succeed, we were left with big questions to answer.

To answer this question we conducted field investigation to confirm the relationship between four variables: (i) Absorption of rural workforce; (ii) Existing practices: Gaharu expedition and wild bee honey collection; (iii) External support: expert, cost, policy; and (iv) Harnessing the existing practice: a shift from gathering gaharu and wild bee honey to cultivation. We predicted that the relationships between those variables are as shown by the direction of the arrows in the conceptual framework of our study (Figure 3).

Based on the conceptual framework the research attempted to describe the relationship between the absorption of rural workforce (Rectangle 1) and the other three variables: existing practices, in this case, gaharu and wild honey bee collection (Rectangle 2), external support, in this case, experts, cost and policy (Rectangle 3), and harnessing existing practices, in this case, a shift from gathering into cultivation (Rectangle 4). The nature of the relationships is shown by the directions of the arrows connecting them. The people's initiatives variable contributes its share to the rural workforce, although with external support it will make more or better contributions.

\section{Data collection}

The research collected primary as well as secondary data. Secondary data was obtained from other parties, such as government, business companies, and other organizations, in which we retrieved these data with prior permission from proper authority. Sources of secondary data for this research included district, sub-district, and village governments. Government data were also retrieved from websites that were updated regularly by government agencies. General data and information was also collected from Indonesian Bureau of Statistic available in annual publication as well as the equivalent via the internet.

Primary data were data specifically collected for this research by the researcher and enumerators. Primary data were collected through in-depth interviews, structured interviews, observation, and focus group discussions. The in-depth interview was an instrument the researcher used to collect detailed information about the area, its people, and local knowledge and local wisdom. The in-depth interviews were conducted with village head, village secretary, school head, and religious leader. For this purpose, a list of topics to discuss with the informants was prepared in advance. The list was made as a guide in the interview, but was not treated as strict rule, because a few things did suddenly turn up during the discussion (Figure 4).

The structured-interview was conducted for the purpose of collecting itemized information. The interviewers were equipped with questionnaires prepared in advance containing mostly multiple-choice questions, but on certain point open-ended questions were included. The subjects of structured interviews were 50 respondents selected using snowball sampling technique. The first respondent was the village head, and from him, direction was requested as to who among his village members would most likely understand the matter under discussion. The observation was conducted without using specific tools other than human faculty which were considered sufficient for performing general observation of the objects. Example of items of observation was the amount of time people spend in doing actual works, such as tapping rubber trees and transporting goods from one point to another including the time used while waiting for customers.

The focus group discussion is a two ways communication procedure in which researchers convey the information that is deemed necessary to prepare the audience to participate actively in the upcoming discussion, and also used to assess the level of agreement among the local population on which project to develop as a way to prepare the population when another economic crisis hit the region. The participants decided for themselves what issue to discuss and what kind of conclusion resulted from the discussion.

During interviews we attempt to elicit three fundamental questions that form the core of our research: (i) How and how much collecting gaharu and wild bee honey absorb rural workforce; (ii) How and how much the idle workforce not included in such two initiatives could be utilized more effectively and efficiently by introducing some external supports; (iii) What kinds of external support have been introduced or could be introduced in order to mobilize the idle workforce not included in the original people's initiatives. 

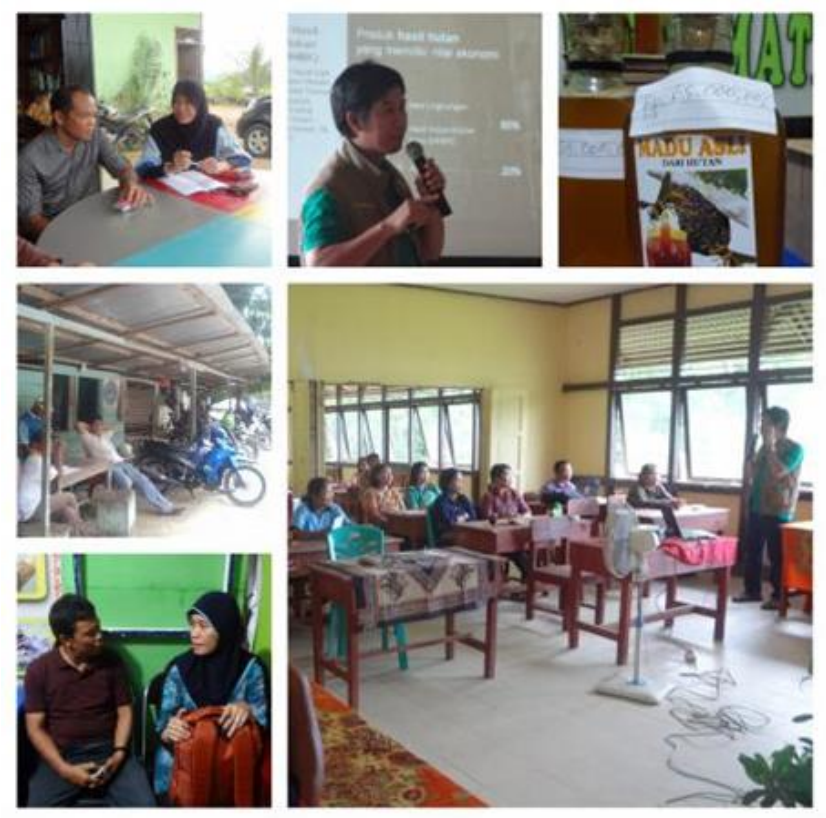

Figure 4. Data collection

\section{Data analysis}

The analysis was conducted following the nature of data collection methods, such as interview, observation, discussion, and document collection. Data collected using in-depth interviews were used to provide narrative containing the history of local initiative in using available natural resources including its difficulty and challenges. Data collected using structured-interview were processed and put into tables and then analyzed verbally. Data collected using structured interviews were used to describe the absorption of rural workforce into various existing economic activities and to evaluate their success and necessary assistant that might be required. This analysis was important for assessing the new initiatives that people had initiated elsewhere, particularly to find out the exact cause that such initiatives failed in this research site. Observation was used to describe the natural environment that could be used as potential sites for future village projects. Based on the observation the researchers evaluated the viability of those projects and determined what kind of input or modification needed to ensure their success. The document collected for this research were used to provide background regarding various aspects of the research sites such as population, infrastructure, natural resources, and general environmental information. This information was important because it provided knowledge about what was existing and how much it had been put into good use, or bad use for that matter.

\section{RESULTS AND DISCUSSION}

The land border is an important feature of Indonesian geography and important asset that poses challenges in Borneo. As an asset, the border area bears potentials for achieving economic growth for the area and wider region.
This means that with proper policy and suitable development strategy the potentials can be converted into real outputs. Hogarth et al. (2013) found that average forest-related income shares of $31.5 \%$ for border community, which was predominantly derived from cultivated non-timber sources. It is especially important for household with lower income levels due to scarcity of other resources.

Many countries that have been successful in grooming their border appearance have received benefit in terms of inflows of capital and labor to the frontier due to changes in the geographic distribution of economic activities leading to the border area (Niebuhr 2006). Progress made in border areas of European countries improves the welfare of the people tremendously. Today many European governments are more worried about non-border areas that have shown worse economic performance compared to the border areas. There is no reason that West Kalimantan border cannot achieve such a feat if proper planning, execution, and management are in place. Such optimism is certainly supported by recent shift in government policy on the border region.

An example of this can be drawn from conservation areas situated within mining concessions, where in-situ conservation can be used as reference points to the eventual post-mining reclamation efforts in said areas (Fiqa et al. 2019). The key point here is that the focus is not on restricting economic activity in favor of environmental protection, but rather to identify ways in which conservation can proceed hand-in-hand with development. According to Nugroho et al. (2017), the prerequisites for good, forest-based spatial planning to achieve sustainable forest management while also respecting adat rights comes down to: (i) whether or not an appropriate institution is available to formulate forest-based spatial planning laws, and (ii) whether or not appropriate mechanisms and tools exists to formulate sustainable forest management technologies that are current and conforms to the aforementioned forest-based spatial planning laws.

\section{Existing conditions and practices \\ Absorption of rural workforce}

This study found that the absorption of local rural workforce into various employment opportunities was relatively low. As a result, the rural workforce had little choice other than going back to traditional employment opportunities in subsistence agriculture and menial labor supplied by various plantations and industries. According to field observation, all of available labor in the border area were put to work regardless of gender and age brackets. Young boys and girls in 'pre-productive age' had their own jobs around the house after they returned from school, likewise, senior people in post-productive age helped the household in whichever capacity their age would allow them to do. That was in fact a good community arrangement since old people remained in the household until the end of their life, and no old age centers were available. The issue was not what modern society called unemployment, which means out of work for certain period of time. These people in fact work all the time, more than 8 
hours a day and 5 days a week which is considered a humane standard of employment.

The real issue concerned with low-level productivity and minimum reward of work. In subsistence rice farming, people spent so much human energy, but still received small return. Whatever amount they produced were needed for their own consumption, however, they often had to sell them at low price to provide cash for other necessities. Considering that it may take a long time to move people out of agriculture, the best choice is to tap agricultural resources with alternative uses aided with some affordable amount of technology and capital input such as one that this research has in mind.

The research couldn't find secondary data concerning occupation of the people in the research site, however, based on interviews with local leaders, this was found: farmer $50 \%$, menial laborer $30 \%$, trader $17 \%$, civil servant $2 \%$, and ojek taxi driver $1 \%$. The farmers included people who cultivate rice and other crops, such as rubber trees, fruit trees, clove and pepper, and vegetable garden at family scale. For example, they cultivated rice on seasonal basis, and when the rice farming was completed they worked on the other crops. If the other crops could not be used for many different reasons, including fruiting season and price level, they opted for menial labor wherever available, sometimes they had to leave their village temporarily or commuted to neighboring villages, town, or neighboring country of Sarawak Malaysia.

The traders included people who owned small shops selling sundry goods to fellow villagers, people who own coffee shops, or people who carry their merchandise on motorcycles, bicycles, or offering produce collected from the forest around the neighborhood. The civil servants work at the village office and sub-district office, and ojek taxi drivers were those who ferried people and goods on motorcycles around the area for some negotiable costs. The phenomenon of shifting occupation was common, caused by the lack of economic activities in the border region and frequent economic gluts the leave people unemployed.

Since the oil palm plantations set their feet in the vicinity, some local workforce had worked in various menial capacities at the plantations, such as planters, house helpers, etc. In the past, there were individuals who specialized in wild honey collection, but after much of the forest was converted into oil palm plantations such profession became story of the past. Nowadays, collecting wild be honey was treated merely as secondary and occasional job for a small number of people. Collecting gaharu resin was also treated as fulltime profession for many people in the past, but this profession also suffered similar predicament as the wild bee honey trackers.

All of those occupations described here receive low to moderate-income. To overcome their lack of income, local workforce often resorted to becoming migrant workers with slightly higher income across the border in Sarawak, Malaysia. In the following text, we show our proposed development model introducing new ways to increase the production level of locally existing resources, in this case gaharu and wild bee honey.

\section{Collection of gaharu}

Gaharu is known by other names as agarwood, aloeswood, oud, and oudh in international market, and those names apply to the tree as well as the resinous substance which is product of the tree. According to Turjaman and Hidayat (2017), in Indonesia, there are 6 species of most common agarwood producing trees, i.e. : Aquilaria malaccensis, A. microcarpa, A. beccariana, and A. hirta in western part of Indonesia. In eastern part of Indonesia, there are Gyrinops versteegii, A. filaria, and A. cumingiana. There are also exotic species planted on very small scale by farmers groups in Deli Serdang - North Sumatera, which are A. subintegra and A. crassna.

The formation of black resinous substance is actually a response of gaharu plants against bacterial invasion via exposed cambium when tree barks are peeled off, broken branches, or through purposely made access by boring or sawing. Gaharu tree takes such incidence as external threat to its existence, and as protection develops fitoalecsin that functions as pathogen against disease. The substance later changes its appearance into black powder with nice aroma that is accumulated in the xylem and phloem of the tree. If the immune system does not work properly, the black pathogen will not develop, and the gaharu simply dies and decomposes.

Collecting gaharu resin has been practiced by local population in the research site and surrounding area since the time of their forefathers. Research informants told the interviewer that in 1914 was the last recorded event when 10 villagers organized a gaharu expedition into the forest around the village. The group was organized under the leadership of a pawang or shaman who was praised for his extensive knowledge about gaharu tracking and mastery of various rituals associated with gaharu collection. The group brought home 2 metric tons of Gaharu resin. That was close to top record of 2.5 metric tons and far exceeded minimum collection of 0.5 metric tons per one expedition.

One of the reasons why gaharu collection was no longer viable was the shrinking of forest area due to economic development, in particular, since the expansion of oil palm plantation into the area. Based on in-depth interview with the head of Adat council in Jagoi Village, it was found that this village possesses large protected forests around Gunung Berunai, Sungai Gombul, Sungai Kam, Sungai Koluh, and other sites. This resource was stipulated as protected forest by decree of Bupati (Head) of Bengkayang District and placed under supervision of Adat Community Forum. Establishment of this adat forest was important to stop expansion of oil palm plantation into the village territory, and therefore save the forest which has been the lifeblood of the Dayak community in this area.

When asked about the possibility of starting a gaharu cultivation project, the villagers simply stated they had no knowledge about such technique. Gaharu cultivation is another economic choice that our study showed to be suitable for helping local population to improve their economic performance. In order to convince the targeted group, the researchers collected relevant information about cultivation of gaharu trees elsewhere and made that information available to local community. Akter et al. 
(2013) suggest exploring the new sources of agarwood in order to protect endangered plant species while at the same time ensure the quantity and quality of gaharu produced by the planted trees.

The economic value of gaharu product is determined by a number of factors, among others is the tree species that provide the substance. The highest price in the market comes from Thymelaeaceae family particularly the genera of Aquilaria, for example, A. malaccensis species which in the commercial circle is named gaharu. Gaharu originated from other tree species is called gaharu buaya which sells for much lower price. The difference is determined by the amount of gaharu substance found in the tree trunk. In general gaharu trade recognizes three classes: gubal, kemedangan, and abu. Gubal has black or brown color, high resin content, and very strong scent. Kemedangan type has weak brown to grey color, softwood, coarse texture, and weak scent. $A b u$ is actually a leftover resulted from the cleaning process of gubal and kemedangan.

To understand the range of agarwood grading system is not an easy feat for newcomer, let alone for novice. There are various grading methods applicable to agarwood oil. Different country has its own way to grade/classify the agarwood oil. Agarwood oil is traded on the basis of qualities; categorized as high quality and low quality. Some countries prefer grades, categorized as A, B, etc. (Ismail et al. 2016). Terminologies used in gaharu market may be confusing for many people, but traders and customers who have been involved in gaharu business for a long time face no problem in discussing gaharu quality and price.

Natural gaharu trees in Indonesia are found in Sumatera, Kalimantan, Sulawesi, Maluku, and Papua. Experienced gaharu hunters can easily recognize trees that contain gaharu resin before they cut them down, but inexperienced ones cut down gaharu trees without knowing its content, therefore many gaharu trees are cut down wastefully. Widespread forest cutting that takes place in Indonesia, coupled with inadvertent cutting of gaharu trees that contain no gaharu resin at all, pose threat to existence of gaharu species. Realizing this worrying development, the Convention on International Trade in Endangered Species (CITES, 2019) in 1994 declared the Aquilaria malaccensis under Appendix II, species that its commercialization is restricted. This decision has forced the government and gaharu entrepreneurs to start cultivation of gaharu trees in estates.

The Research and Development Agency for Forest and Nature Conservation of the Ministry of Forestry in Indonesia is conducting gaharu product reengineering. The research conducted in 2000 showed that gaharu stands could be cultivated in plantation. High price of gaharu resin that can reach tens of million IDR per $\mathrm{kg}$ (in 2019, 1 US\$ equal to IDR 13,900) and finding that gaharu resin could be processed into herbal medicine to cure serious illnesses such as tumor, cancer, liver, tuberculosis, and kidney diseases, had spurred wide interest to preserve natural gaharu and develop gaharu estate at the community level.

Examples from Menyang Taih Longhouse in Batang Ai Sarawak show that gaharu tree does not only produce gaharu resin, in fact, Aqularia microcarpa also produces valuable leaves that can be processed into herbal tea that has numerous health benefit. Since 2017 this area already planted more than 30,000 gaharu trees in 6 hectares of land and already produced instant tea in bags and sold in the market in Sarawak (WWF-Indonesia West Kalimantan Program, 2018)

All of the information outlined here were discussed with research participants and those who wished to cultivate gaharu trees were suggested to contact the Forestry Department who would provide accurate scientific information and advise on gaharu trees cultivation.

\section{Collection of wild bee honey}

Collecting wild bee honey is a cultural event for local community in Jagoi Village and surrounding area. Bees are believed to have some magical power and give highly valued benefits in the form of wild honey to the people. Therefore, people are not allowed to kill the bees. Whenever necessary, for example, during honey harvest, they merely chase the bees away temporarily using sparks emitted from burning torches made of natural straws. During the honey removal process, they sing traditional verses to appease the bees. In one community in Central Kalimantan, members of the harvest team avoid calling each other by names, instead, they call each other by beruang or bear as if to hide their human identity while robbing the honey or trying to scare the bees and make them think that the nasty bear who take away their tightly guarded honey sacks.

The population of Jagoi Village has been collecting wild bee honey from the surrounding forest since as long they could remember, therefore the inception of the adat forest would guarantee the availability of resource for them to practice their trade. Collecting wild bee honey is not like collecting seashell along the beach. First of all, bees made their nest in safe places, hanging down under long branches high up on tall Ketapang trees (Terminalia catappa species of Combretaceae family), sometimes sixty meters up. The nest was covered with the bodies of live bees, some of them were protection soldiers armed with painful sting.

To retrieve the honey, first, they must climb the tree without the help of safety gears, literally barefooted and barehanded. On very tall and big tree they attached small $\log$ on tree side and used the small $\log$ for climbing. Climbing the tree is difficult enough, but that is nothing compared to moving above long branches to reach the nest. No one will tell how they do it; perhaps, that is one of the mysteries that tree climbers want to keep for themselves. Then they had to negotiate with the swarm of bees. To minimize the bees attack and perhaps also their fear of height, collecting wild bee honey is usually done at night. After clearing the nest with their torches they quickly cut the nest with their machete and put it in a bucket which they carry along during the climb.

In the research area, wild bee nest found in the forest belonged to the person who finds the nest and leave his or her mark around the tree, however, bee nest on a tree in private land belongs to the landowner. In any case, traditionally collecting wild bee honey rarely poses any 
conflict, since harvesting bee honey cannot possibly be done by one single person. Whoever the owner always ask other people to join, especially people who have experience in collecting wild bee honey. Everyone who joins the activity already knows in advance how the honey will be divided between the owner and other participants. According to research informants, one normal size nest produces $15 \mathrm{~kg}$ of honey.

The villagers said that today to find honey bee nests in the forest is not as easy as in the past, and people who were prowess in climbing tall trees and harvest the honey were rare, therefore they were eager to learn if someone would teach them how to farm honey bees, so they would not have to venture into the forest to find their nests. To accommodate their wish, the researchers looked around for necessary information on honey bee cultivation and invited experts to talk about wild bee honey project management. Among the information that was supplied to the local community and which were discussed with the expert includes: best practice in honey harvest, honey quality, and honey market.

In practice we often witnessed people retrieve honey from its nest improperly, such as taking the whole parts of the nest while in reality, not all the parts contain honey. Actually, there is a healthy and more productive method of wild bee honey retrieval. Therefore sustainable harvest of wild honey which includes leaving $25 \%$ of nest's head for feeding the larvae; and hygienic treatment of tools to protect honey quality is mandatory (Oldroyd and Nanork 2009).

Proper harvest method as described in the previous paragraph should be followed up with equally proper processing to insure natural taste of honey. The method referred to here is call the Tiris method. The process begins with removing the wax that covers the nest, then put the nest in the filter and let the honey slowly pass through without using the hands to squeeze the honey out of the nest. According to Kohl and Rutschmann (2018), changing the perspective/treatment of bees from domesticated animal and recognizing that the honey bee can also live as a wild animal is necessary for achieving a full understanding of its biology

Wild bees in Indonesia that produce honey sold in the market consisted of several species, such as Apis andreniformis, A. dorsata, A. cerana, A. koschevnikovi and A. nigrocincta (Hadisoesilo 2001). When people want to buy honey in the market, they always insist to get genuine natural honey, but most of them do not have the necessary knowledge about the characteristics of pure wild bee honey. Wild bees of Indonesia is famous for its natural quality that contains nutritional value for human health. Such complete nutritional composition when consumed by human will have positive effect on human health including: help building stamina for pregnant mother, improving children appetite and providing nutrition and vitamin; recovering stamina and vitality; relieving coughing, flue, oral ulceration, stomachache, tonsilitis, and throat infection; help curing for asthma, diabetes, heartburn, cholesterol, anemia, heart, and cancer etc., and smoothing facial tissue, black dots, and acne.
In this study, information on honey bee farming was collected from various sources and relayed to the community as preparation for building their own bee honey facility. In Sentarum Lake, Kapuas Hulu West Kalimantan, WWF West Kalimantan Program has for years assisted local fishermen in farming of wild bee honey starting from managing honey bee colony, harvesting, packaging, and certification of healthy honey product for global marketing. So, if the people in the research site still struggle to establish their business, they can learn from WWF or Sentarum lake fishermen.

\section{Proposed model of employment creation}

The model of optimal absorption of rural workforce proposed in this research attempts to integrate several elements derived from people activities, sponsor and donor participation, and related government departments in promoting sustainable use of natural resources and creation of new employment to improve community socioeconomic conditions and general welfare. Ludvig et al. (2019) identified economic and social issues as two combined complementary sources of income.

The promoted model accommodates certain principles, including sustainable development, conservation of natural resources, preservation of endangered species, protection of important resources, and rehabilitation of degraded resources. This criteria is relevant to the suggestions given by the researchers to local community. Cultivation of agarwood estates and farming of honey bees in honey boxes are example of sustainable use of natural resources. These strategies are conservation-friendly employment creation because it changes the mode of production from 'collection' into 'cultivation'. These are also in line with the preservation and protection of endangered flora species, such as the Aquilaria malaccensis. The existence of wild honey bees depends on available nesting trees. In fact, many forest stands have been cut and some areas are left barren and turn into critical land. Therefore, a great deal of rehabilitation activities is in urgent need. If all these criteria are in place, we feel confident that new employees will be created and family income and social welfare will be much improved.

The gaharu cultivation and honey bee farming under the approach of reforestation using tree species that are commonly used by wild bees to build their nests or by nursing the bees in manmade facilities are in line with the new government paradigm of the green economy. Loiseau et al. (2016) provided an attempt for operationalizing green economy. The practice of green economy in Indonesia can be found for example in Aceh (see Swainson and Mahanty 2018). The two strategies suggested by this research (gaharu cultivation and honey bee farming) if managed properly will create alternative employment and additional income, and improvement of environmental quality, particularly the forest. Along the same line of thought, Gunatilleke (2015) discuss that economic valuation of ecosystem services will provide decision-maker with better understanding in effort for wealth creation and jobs in a green growth sector. 


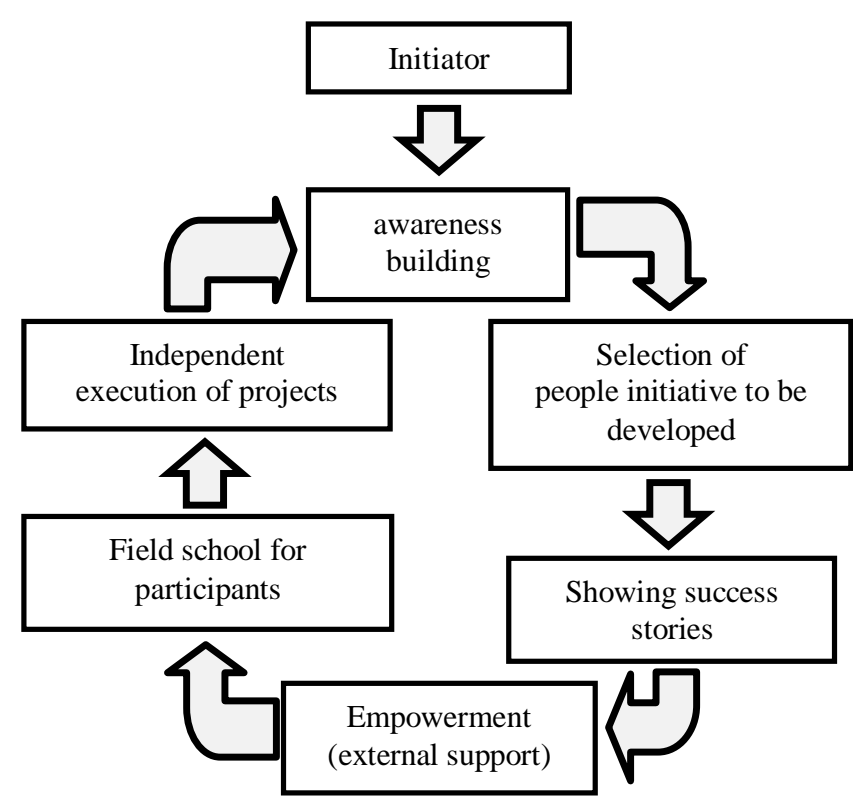

Figure 5. The model for optimal absorption of rural workforce

\section{Reconstruction of the model}

One of the objectives of our study was to verify the feasibility of a model for increasing absorption of rural workforce through harnessing local initiatives with external support (Figure 2). The results of our study did not only support the model but also introduce new elements that are crucial for implementing the model in real situations, namely building community awareness and conducting field school. Therefore, our original model needs to be reconstructed by adding those two elements as shown in figure 5 .

The model was constructed using seven rectangles that are properly labeled and placed in orderly position to allow positioning of arrows that show their relationship with each other. The points of the arrows show direction of the process of action that the initiator has to follow in order to get maximum benefit from the model.

\section{The initiator}

The initiative for conducting projects relevant to the proposed model (i.e. gaharu cultivation and honey bee farming) to improve rural workforce productivity may come from the government, donor NGO, and the people themselves. The NGO or the government agency in charge must make sure that the people have sufficient awareness of their condition and are fed with sufficient information about the project to be implemented.

\section{Awareness building}

Awareness is an important concept that needs to be considered before anyone decides to implement a program or project designed to help local community to improve their socio-economic condition. According to Sengupta (2010), environmental awareness has broad connotation. It consists of knowledge about environment, as well as attitude, values, and necessary skills to solve environment- related problems. Moreover, environmental awareness is the initial step ultimately leading to the ability to carry on responsible citizenship behavior. Such definition fits perfectly with the situation faced by the community in Jagoi Village.

Awareness building is a conscious effort by the initiator to make the participants or community members capable of perceiving about what happens around them and make their own decision whether to keep or to change some element to make their life better. Such awareness is an important ingredient for any outside assistant to succeed, because the community will not be able to make intelligent decisions unless they understand the issue, potentials, and challenges facing each alternative presented to them. During this awareness campaign, the initiator introduces to the community various concepts that are likely to gain support from various stakeholders if those concepts are incorporated into the model. Those concepts are explained to the community using vocabulary that is suitable in view of the general level of education and experience of the target community. In our research, this objective was achieved through communication that took place during data collection, particularly during focus group discussions which were held in several sessions.

\section{Selection of alternatives}

At the end of the awareness campaign, the initiator as well as the targeted community should have a very clear idea about what they want to do. In our research, the targeted community selected two projects to develop namely Organic Wild Honey Cultivation and Gaharu Wood Cultivation. Both of these projects fulfilled all the criteria of the model as described in the previous section. We agreed that 'collecting' both products in the wild is no longer viable, because most of the people were reluctant to do it and wild bee nests were hard to find in the surrounding forest. The term organic was added at a suggestion from an expert invited as instructor at the study session. In this case, organic means that no other substances, such as sugar and water, would be added to the product, and all of the maintenance processes of both projects should be done following clean and healthy practices.

\section{Looking for successful project as example}

After the projects to be executed have been decided, the initiator looks for financiers or donors and experts in the field of activity. The experts will be appointed as instructors in the field school organized to improve people's knowledge on various aspects of the project, especially since the project will be done by the people themselves. Our research was involved in preparing and feeding necessary information and knowledge about those two projects to the research participants.

\section{Empowerment (external support)}

The initiator assumes the responsibility of recruiting the experts who will teach the target population all the necessary knowledge and skill in performing various tasks related to execution of the projects. The initiator also helps 
the community to find potential donors to finance the activity. Our research recruited those experts by way of 'expert cooperation' with appropriate office and organization.

\section{Conducting field school}

In the field school, the experts teach the community all the necessary knowledge and skills related to the execution of the project at hand. In the field school, the participants are taught theories and processes through modules prepared in advance. At the end of the class session, the participants are brought to the field to see for themselves how the knowledge and skills are put into practice. An example of a field school is given by Manual Restorasi (Restoration Manual) published by WWF-Indonesia (2018) for its restoration program in West Kalimantan which include: construction of seeding center, selection of species and estimating seeds requirement, land preparation and planting, plant care (weeding and replacement), and monitoring of plant growth.

\section{Construction of project}

All of the steps beginning with the initiator's activity to explore the level of awareness of the targeted community, selection of alternative projects to be implemented, recruitment of expert, donor, and supporter, and implementation of the field school are necessary to process leading toward execution of the project. The role of the initiator continues as supervisor who assists the community with finding solution should emergency, challenges, and problems arise.

\section{Additional employment}

Since the first step and every other step thereafter the Model accommodates active participation of the targeted community. As the activity is designed with support from sponsors, the people's participation is in fact a form of short-term employment. Later, when the project is implemented, their full participation is required and continues into production and maintenance. In our research, we call it 'optimization of rural workforce absorption'.

In conclusion, in the study area, the absorption of rural workforce into the formal sectors was low. This fact may be true, but describing that rural population is generally unemployed was also not necessarily accurate. Our research showed that rural workforce worked longer than 8 hours a day and 5 days a week considered humanly limit in formal sectors. Even young people and senior citizens were not spared from doing various works around the house to let members in productive age bracketed work outside the house to earn some cash to make the household running and healthy. We admit that the arms of development have reached the rural area in the border region, and many work opportunities were there for those who can reach them. But, in most cases, due to lack of education and skill, the rural workforce had to compete among themselves for lowlevel job with low take-home income. Those who were unlucky would have to resort to informal sectors working as traditional farmers, rubber tappers, coffee shop attendants, ojek taxi drivers, and various other menial jobs with low job security and reward.

The two commodities that the rural workforce was once very familiar with and viable option in some portion of the year, the gaharu and wild bee honey, for some reason are no longer available for them. Our research finds that these two commodities remain viable potentials, if we could provide modification and add new elements in their pursuit. In order to achieve this objective, we propose to reconstruct the research conceptual framework (Figure 2) and turn it into a new model by adding three new elements namely awareness building, showing success stories taken from other communities, and conducting field school to improve communities' knowledge and skill. As such, this new model consists of a series of steps to be followed which include: (i) awareness building; (ii) promoting people's initiative; (iii) showing success stories taken from other communities; (iv) recruiting external expert and other resources on the chosen commodities; (v) conducting field school for the community; (vi) execution of the project chosen by the communities. This model is quite simple and easy to explain by using Q\&A methods, and the step by step process can be quickly understood by the targeted communities in the border area and elsewhere. Our research team has made a commitment to assist the local community throughout those 6 steps to ensure that they are implemented correctly and all the external requirements are there to be used.

\section{ACKNOWLEDGEMENTS}

The author gratefully acknowledges financial support from Universitas Tanjungpura, Indonesia through 7 in 1 Research Grant.

\section{REFERENCES}

Akter S, Islam MT, Zulkefeli M, Khan S I. 2013. Agarwood production A Multidisciplinary field to be explored in Bangladesh. Int J Pharm Life Sci 2 (1): 22-32. DOI: 10.3329/ijpls.v2i1.15132

Azra M. 2015. Dependence of local communities on forest resources: Implications for protected area management in Melghat Tiger Reserve, Maharashtra, India. Int J Ecol Environ Sci 41 (1/2): 101-110.

Clark MR, Kozar JS. 2011. Comparing sustainable forest management certification standards: A meta-analysis. In Ecol Soc 16 (1). DOI: 10.5751/ES-03736-160103

FAO. 2013. Promoting decent employment in forestry for improved nutrition and food security.

Filho JBSF, Fachinello AL. 2015. Employment and income generation in the Brazilian Amazon forest: a Social Account Matrix-based multiplier approach. Int For Rev 17 (1): 85-96. DOI: 10.1505/146554815814669007

Fiqa AP, Fauziah, Lestari DA, Budiharta S. 2019. The importance of insitu conservation area in mining concession in preserving diversity, threatened and potential floras in East Kalimantan, Indonesia. Biodiversitas 20 (1): 198-210. DOI: 10.13057/biodiv/d200123

Gunatilleke N. 2015. Forest sector in a green economy: A paradigm shift in global trends and national planning in Sri Lanka. J Nat Sci Found Sri Lanka 4 (3): 2. DOI: 10.4038/jnsfsr.v43i2.7937

Hadisoesilo S. 2001. The diversity of indigenous honey bee species of Indonesia. Biodiversitas 2 (1). DOI: 10.13057/biodiv/d020107

Hogarth NJ, Belcher B, Campbell B, Stacey N. 2013. The role of forestrelated income in household economies and rural livelihoods in the 
border-region of Southern China. World Dev 43: 111-123. DOI 10.1016/j.worlddev.2012.10.010

Homma AKO. 1996. Modernisation and technological dualism in the extractive economy in Amazonia. Current issues in non-timber forest products research, 59-82.

Ismail N, Rahiman MHF, Taib MN, Ibrahim M, Zareen S, Tajuddin SN. 2016. A review on agarwood and its quality determination. Proceedings - 2015 6th IEEE Control and System Graduate Research Colloquium, ICSGRC 2015. DOI: 10.1109/ICSGRC.2015.7412473

Kanwal V, Pandey D, Suhasini K. 2017. Impact of forest development programme on livelihood of rural people in Nainital district of Uttarakhand. Indian J Econ Dev 13 (2a) : 369-374. DOI: 10.5958/2322-0430.2017.00172.x

Kikuchi R. 2011. The role of agroforestry development in transition from neoclassic economy to bio-based economy. Agricultural Economics: New Research.

Kimengsi JN, Ngala MP. 2018. Revisiting participatory forest management and community livelihoods in the Kilum-Ijim Montane forest landscape of Cameroon. Int J Global Sustain 2 (1): 39-55. DOI: 10.5296/ijgs.v2i1.12766

Kohl PL, Rutschmann B. 2018. The neglected bee trees: European beech forests as a home for feral honey bee colonies. PeerJ: e4602. DOI: 10.7717/peerj.4602

Loiseau E, Saikku L, Antikainen R, Droste N, Hansjürgens B, Pitkänen K, Leskinen P, Kuikman P, Thomsen M. 2016. Green economy and related concepts: An overview. J Cleaner Prod 45: 1-8. DOI: 10.1016/j.jclepro.2016.08.024

Ludvig A, Zivojinovic I, Hujala T. 2019. Social innovation as a prospect for the forest bioeconomy: Selected examples from Europe. Forests 10 (10): 878. DOI: 10.3390/f10100878

MacDicken KG, Sola P, Hall JE, Sabogal C, Tadoum M, de Wasseige C. 2015. Global progress toward sustainable forest management. For Ecol Manage 352: 47-56. DOI: 10.1016/j.foreco.2015.02.005

Ng'andwe P, Mwitwa J, Muimba-Kankolongo A. Kabibwa N, Simbangala L. 2015. Contribution of the forestry sector to the national economy. Forest Policy, Economics, and Markets in Zambia, Academic Press. DOI: $10.1016 /$ B978-0-12-804090-4.00004-5

Niebuhr A. 2006. Spatial effects of European integration: Do border regions benefit above average? Review of Regional Studies. DOI $10.2139 / \mathrm{ssrn} .660022$

Nugroho, Hunggul YSH, van der Veen A, Skidmore AK, Hussin YA. 2018. Expansion of traditional land-use and deforestation: a case study of an adat forest in the Kandilo Subwatershed, East Kalimantan,
Indonesia. J For Res 29 (2): 495-513. DOI: 10.1007/s11676-0170449-9

Oldroyd BP, Nanork P. 2009. Conservation of Asian honey bees. Apidologie 40 (3): 296-312. DOI: 10.1051/apido/2009021

Paoli GD, Peart DR, Leighton M, Samsoedin I. 2001. An ecological and economic assessment of the nontimber forest product gaharu wood in Gunung Palung National Park, West Kalimantan, Indonesia. Conserv Biol 15 (6): 1721-1732. DOI: 10.1046/j.1523-1739.2001.98586.x

Presidential of Indonesia, Regulation No. 12 Year 2010 on National Agency for Border Management. https://peraturan. bpk.go.id/Home/Details/41036/perpres-no-12-tahun-2010. [Indonesian]

Research Center for Biology - Indonesian Institute of Sciences (Indonesia CITES Scientific Authority) and Director General of Forest Protection and Nature Conservation - Forestry Department (Indonesian CITES Management Authority). Report on NDF of Agarwood for Sustainability Harvest. https://cites.org/ sites/default/files/ndf_material/.

Sengupta M. 2010. Environmental awareness and environment-related behaviour of twelfth-grade students in Kolkata : Effects of Stream and gender. Anwesa 5 (1): 1-8.

Soehartono T, Newton AC. 2002. The gaharu trade in Indonesia: Is it sustainable? Econ Bot 56 (3): 271-284. DOI: 10.1663/00130001(2002)056[0271:TGTIII]2.0.CO;2

Swainson L, Mahanty S. 2018. Green economy meets political economy: Lessons from the "Aceh Green" initiative, Indonesia. Global Environ Change 53: 286-295. DOI: 10.1016/j.gloenvcha.2018.10.009

Turjaman M. Hidayat A. 2017. Agarwood-planted tree inventory in Indonesia. IOP Conference Series: Earth Environ Sci 54 (1). DOI: $10.1088 / 1755-1315 / 54 / 1 / 012062$

Watson JC, Wolf AT, Ascher JS. 2011. Forested landscapes promote richness and abundance of native bees (Hymenoptera: Apoidea: Anthophila) in Wisconsin apple orchards. Environ Entomol 40 (3): 621-632. DOI: 10.1603/EN10231

Wollenberg EK. 2001. Incentives for collecting gaharu (fungal-infected wood of Aqualaria spp.; Thymelaeaceae) in East Kalimantan. Econ Bot 55 (3): 444. DOI: $10.1007 /$ BF02866565

WWF-Indonesia West Kalimantan Program. 2018. Green Inspiration from Cross-Border Visit. ICI Cross-Border Visit, Sarawak, Malaysia. August 20-26 2018. [Indonesian]

WWF-Indonesia. 2018. Manual Restorasi. WWF-Indonesia Program Kalimantan Barat, Pontianak. [Indonesian] 